Article

\title{
Copyright Management by Contemporary Art Exhibition Institutions in Poland: Case Study of the Zachęta National Gallery of Art
}

\author{
Anna Pluszyńska \\ Faculty of Management and Social Communication, Jagiellonian University, 4 Łojasiewicza Street, \\ 30-348 Krakow, Poland; anna.pluszynska@uj.edu.pl
}

Received: 12 May 2020; Accepted: 29 May 2020; Published: 2 June 2020

\begin{abstract}
The mission of cultural institutions is the expression of sustainable development, which assumes a specific social order based on respect for the right of access to culture and care for the common good which is cultural heritage, in order to preserve it for future generations. To best implement its social mission, the essence of museum activities is not only collecting resources but also promoting the collection. In addition, promotion in accordance with the principle of openness and the conviction that cultural heritage is a common good, which is why it should be available to the widest possible public. Copyright in artworks often stands in the way of implementing an open approach to the dissemination of collections. Contemporary museums and galleries of art are in a special situation; their collections are not yet in the public domain, and so they cannot be freely distributed. The undertaken research problem explores how cultural institutions in Poland manage the copyright of collections in order to carry out their mission in a sustainable way. In this context, copyright is treated as an important intangible resource of a cultural institution. The case study was used as the research strategy in order to understand the subject. Activities implemented at the Zachęta National Gallery of Art in Warsaw were described.
\end{abstract}

Keywords: copyright management; open policy; exhibition institution; the Zachęta National Gallery of Art

\section{Introduction}

It is a truism that the issue of sustainable development should and does have an interdisciplinary quality, much unlike many other topics. This article looks at the mentioned issues from the point of view of copyright for creative work which-although dominated by lawyers-is characterized by a similar interdisciplinary nature. Hence, copyright issues will be presented as intangible goods that are objects of management processes. The main point of reference will be the system of national law, specifically of Polish law, although it obviously does not function in isolation from international law regulations.

Beginning a dialogue about the place of the concept of sustainable development and its connections - or the possible connection with the issue of copyright—we should start by determining what is characterized by development called sustainable. At least two elements should be emphasized in this concept. Perhaps this approach may seem a simplification, but even though it does not show a wealth of issues, it is sufficient for the purposes of this article. First, the function of sustainable development is to balance the interests of four interrelated systems: social, environmental, economic and cultural [1]. The second important element is durability, which was formulated in one of the most popular definitions of sustainable development as such "that meets the needs of the present without compromising the ability of the future generations to meet their own needs" [2]. 
The relationship between copyright issues and the issue of sustainable development has its origin in constitutional law. The current Constitution of Poland, as the basic source of law, was established in 1997. It contains references to the sphere of culture with the idea that the role of the state is to look after cultural activities but also to stimulate development. In this case, culture is both public, social and private, related to the cultural needs of the citizens of the country to whom the Constitution is primarily addressed [3] (p. 10). In this context, two constitutional rules are fundamental: the principle of equal access to cultural goods (Article 6 (1) of the Constitution) and the principle of freedom of artistic creation and the freedom of use of cultural goods (Article 73 of the Constitution).

These cultural rights are to a large extent linked to the sustainable development of culture, in particular through the need to move toward a democratization of access to cultural heritage. Democratization in this context is understood as the removal of borders, including financial barriers to access culture. When the limitation of physical prowess loses importance, for many people the impossible becomes possible. A significant role in this process is played by public cultural institutions, which in order to achieve sustainable development should limit or eliminate activities that disturb this development.

Public cultural institutions manage the common good. The English word 'commons' was primarily used to describe communal pastures where all village residents could graze their cattle [4]. As Merete Sanderhoff writes, the common good is a cultural heritage: "cultural heritage belongs to everyone. It was created by-and for-all people" [5] (p. 9). This is valuable not only because it arises and should be protected for future generations but also because it is a source of inspiration, a starting point for development, i.e., further creativity, which is why it should be available to the widest possible public [6].

This article focuses on the activities of museums and galleries of modern art, whose mission is to protect and promote the collection of artworks. However, the way of understanding the mission has changed over the last few decades [7] and a movement can be observed from a focus on collecting objects to building relationships with recipients [8,9]. The evidence of this is in the official museum definition adopted by ICOM (International Council of Museums), which in 1974 was supplemented with the phrase "in the service of society and its development" [10]. In this particular sense, in recent years the process of digitizing heritage resources has increased in importance. This is extremely evident during the COVID-19 pandemic. The relationship has radically expanded thanks to a group of public institutions' recipients, as "they are not only those who go through the doors of galleries or museums but potentially all who have access to the Internet" [6]. However, Laurajane Smith believes that access to collections is just the beginning. The cultural object itself does not prove the importance of cultural heritage by itself but by how it is used [11]. This means that if we assume cultural heritage is a common good-from the perspectives of recipients-access to the "collection in the form of files stored on servers will be no different from those kept in warehouses. Therefore, a citizen who is a co-owner of this resource expects not only access, but also the possibility of using the heritage according to their own needs and rules in accordance with the law" [6] (p. 11). Hence, public cultural institutions should adopt the strategy of sharing heritage in the most open manner, enabling its reuse by users. Similar postulates are formulated, among others, by Europeana [12], a European public digital library set up by the European Commission or the European Digital Agenda [COM (2010) 245] [13], which already in 2010 recognized digitization and the broad sharing of collections as one of the key social challenges. In addition, according to the NMC Horizon 2016 report Museum Edition, the creation and sharing of free cultural resources is currently the social responsibility and determinant of world-class institutions [14]. Broad access to digitized resources of cultural collections in accordance with the policy of open access is an element of the social mission of cultural institutions.

From the point of view of this article, however, it is of importance that the growing awareness among employees of cultural institutions about the need to implement an open model goes hand in hand with a sense of uncertainty related to copyright, which does not allow to fully utilize the potential of institutions' resources [6,15]. Here, copyright is understood as an intangible resource of an 
institution that conditions the possibility of sharing collections. This also depends on the possibility of the free use of resources by users. Therefore, copyright is a necessary resource that enables the implementation of the mission of cultural institutions. Difficulties in implementing the institution's mission 'in the spirit of' sustainable development refer not only to the lack of knowledge of the law but above all to the lack of standards that would facilitate building the collection and the storage and sharing of heritage resources.

The World Intellectual Property Organization (WIPO), a specialized United Nations organization that coordinates and creates regulations regarding the system of intellectual property protection, has underlined for many years the importance of copyright in cultural institutions, emphasizing their role in the management process [16]. That is why the WIPO recommends the implementation of copyright management policy in cultural institutions, which first of all allows us to assess the potential capabilities of the institution in carrying out its mission. Secondly, it allows for a consistent way of making copyright decisions that ensures quality throughout the organization. A museum's copyright policy is a set of rules that provide guidance to employees when deciding how to use the collection's resources.

The purpose of this paper is to identify the impact of the adopted policy for managing the copyright of the collection on the implementation of the exhibition institutions mission. Importantly, I will discuss it based on the current legal system, as it is not my intention to discuss the need to change the law. The considerations will largely focus on local Polish activities. This is primarily due to legal differences. Up until now, this issue found no interest among researchers, so I decided to discuss this topic based on the case study of the Zacheta National Gallery of Art. The analyzed case, albeit from Poland, aims to present examples of operating that may be an inspiration for other exhibition institutions, including ones abroad.

\section{Theoretical Background, Literature Review}

\subsection{Museums and Galleries of Contemporary Art: The Mission of Public Exhibition Institutions in Poland}

The definition of a museum that is widely respected and used around the world was developed by the International Council of Museums (ICOM) based in Paris, which operates as a UNESCO consultancy organization. The first definition appeared in the ICOM 1946 Constitution, but it has since evolved over the years to assume the following shape in 2007: "A museum is a non-profit, permanent institution in the service of society and its development, open to the public, which acquires, conserves, researches, communicates and exhibits the tangible and intangible heritage of humanity and its environment for the purposes of education, study and enjoyment" [17].

In 2019, ICOM proposed to update the above definition, that will be subject to a vote [18]. This definition, although much longer, to an even greater extent emphasizes the need to build relationships with recipients.

In my article, I will focus specifically on legislation in Poland. According to the Polish Museum Act of 21 November 1996 (Article 1), “The Museum is a non-profit organizational unit whose purpose is to collect and permanently protect the natural and cultural heritage of humanity, both material and immaterial, informing of the values and content of the collections, disseminating the basic values of Polish and world history, science and culture, shaping sensitivity and aesthetic cognitive, and enabling the use of collections".

The Polish legislator clarifies the definition of a museum in the next article of the Museum Act, indicating how the formulated institution goals should be achieved. The current Museum Act was established in the 1990s and since then the catalogue of museum tasks has undergone significant changes. Their scope was expanded, which was associated with growing social expectations regarding a change in how museums work and, in particular, in terms of communicating with recipients. As Rafał Król writes, 
"A museum cannot be just a storehouse for exhibits. It is not enough. We cannot afford it. Such costs as storage, conservation, supervision, and heating are huge. Citizens must have the opportunity to commune with as many cultural goods as possible. What is the public benefit of an artwork that you cannot experience because it is in the storehouse? Beside the fact of its storage and protection, none" [19] (p. 21).

According to Rafał Golat, the legislator imposed socially useful goals and tasks on museums, which are implemented in two main areas: protection and dissemination [20]. The museum's task is to uphold museum collections and leave them to the future generations by further disseminating culture in a way that is attractive to recipients. Museum institutions, therefore, face a major challenge to contribute to sustainable development. Hence, it is not only that museums protect, disseminate and store collections. This is important because, thanks to this, the collections, despite the passage of time, continue and remain available. Katarzyna Barańska even writes that a museum collection, as an inalienable property of a given museum, should be the starting point-and endpoint-for all kinds of museum activities [21]. But if we stop at collecting and protecting the collection, museums will still be referred to as cemeteries, even mausoleums, as the resting place of inanimate objects [22]. Therefore, the essence of the much needed changes is finding a balance but not in the content of the museum's mission but in how it is implemented [23].

As Peter Vergo points out, the museum's function is to preserve the past so that it can be passed on to the future generations [24]. As Katarzyna Zalasińska rightly notes, museums "not only preserve heritage but also define our cultural heritage. This is mainly expressed in their collecting activity" [23] (p. 12). Wojciech Kowalski and Paulina Gwoździewicz point out that the collection should be created "according to the previously established key: artistic, cultural, historical, scientific, cognitive or yet another" [25]. This means that the collection construction in a museum should not be accidental. If museum collections were collected in isolation from the institutional mission, there would be a likelihood of "trivializing them and entering areas that ... should be called hoarding rather than conscious and responsible collecting" [26] (p. 75). This is a fairly important aspect in the case of public museums, which should operate according to established goals and pay attention to the fact of social responsibility [26]. What is more, the program of museum activities flows from the structure of its collections [23].

Particular challenges are faced by contemporary art museums whose mission is to awaken an interest in art created in the times we live in, not the one that history has already "popularized" [27]. According to Marta Kudelska, "museums focused on modern art still work for social trust" [28] (p. 192). It is hardly surprising, then, that apart from protecting collections, these institutions place great emphasis on educational and sharing activities or organizing and conducting cultural activities.

Museums of contemporary art are a novelty in Poland, besides the Museum of Art in Lodz, operating since 1931. The art of the 20th century is the area of interest of many Polish institutions, but there are only a few specialized museums. New branches were created, among other places, in Wroclaw (Wroclaw Contemporary Museum), Krakow (Museum of Contemporary Art in Krakow MOCAK) and Warsaw (Museum of Modern Art). Many other museums also have divisions dedicated to contemporary art; for example, the Museum of Contemporary Art is a division of the National Museum in Szczecin, while the Museum of Contemporary Art is a division of the Museum of Jacek Malczewski in Radom [29].

Katarzyna Jagodzińska pays attention to doubts that arise about whether the word 'museum' can be used along with the word 'contemporary'. Can contemporaneity be presented in a museum and will the present be still contemporary? [30] The author notes that it is very difficult for museums to part with historical works, which is why many institutions find it difficult to maintain the contemporary nature of the collection [30]. But contemporary artistic creation is also found in other institutions which, although they are not museums, have much in common. In German-speaking countries, a Kunsthalle was very popular. In other regions, such institutions took the form of art centers, galleries and institutes. Although they are not burdened with the symbolism of the word 'museum', this does 
not change the fact that a large part of them build their own collections but often smaller than museum collections. The Society of the Friends of Fine Arts, founded in 1854 in Krakow, has the longest tradition among institutions dealing with contemporary art in Poland. However-analogous in its formula-the Society for Encouragement of the Fine Arts in Warsaw, which was created in 1860, played an essential role in promoting contemporary art in Poland. This society created the most important art institution in Poland in the 19th and 20th centuries [30]: the Zacheta National Gallery of Art, which is the only state gallery subordinated entirely to the Minister of Culture. Besides that fact, the vast majority of public galleries now have the status of municipal or regional institutions, although they often stem from state art galleries, that is from Art Exhibition Offices, a phenomenon in itself and probably the only such formula of the network of cultural institutions in the world before 1989 [31].

To summarize this part of my considerations, exhibition institutions face a big challenge, especially those with modern art in their collections. A proper understanding of their mission requires finding balance. On the one hand, these institutions should be a bastion of heritage that should be protected from destruction or misunderstanding [32]. On the other hand, they cannot separate art from life, so they must undertake educational activities and even inspire the community for creative or innovative activities. These activities undertaken by public exhibition institutions are not contradictory but require such sustainability that guarantees the protection of cultural goods while not threatening current and future generations in the use of their own heritage.

\subsection{The Importance of Copyright in Exhibition Institutions}

The objects of protection under the Polish Copyright and Related Rights Act of February 4, 1994, are intangible goods such as artistic, literary or scientific works and related rights goods, including artistic performances. Copyright, as a type of intellectual goods, is the result of human creativity, so it is a resource closely related to the human individual, in the sense that it is 'generated' by the creator. The primary copyright owner of the creative work is the one who makes the work. There is a dualistic model in Poland, characterized by the separation of two autonomous types of copyright: personal and material copyright. Personal copyright protects the connection between an author and their work, in particular the right to authorship. It is not transferable and is without a time limit. However, material copyright is aimed at securing the economic interest of the creator or copyright-holder. It is tradable, which means that they can be placed on the market. It is also time-limited, so 70 years after the artist's death, the work goes to the public domain and can be freely operated without the author's-and their legal successors' - consent. However, there is a condition in the Polish copyright system. Personal rights that do not have a time limit must still be respected.

Copyright in this paper is understood as an intangible resource of an organization, which can be created into an organization or order/bought/obtained from the creators. As a value that can be used in the creation, sharing or exploitation process.

The characteristic features of intangible resources, including copyright, are:

- uncountability;

- impossibility of wear during use;

- $\quad$ excellent liquidity, in the sense that they can be transformed into any material resource [33] (e.g., copyright can be turned into a source of financing);

- a close relationship with the human individual, in the sense that intangible resources are 'generated' by a person and developed in a human mind.

As a type of intellectual goods, copyright exists regardless of things. In other words, things are not a condition for their existence. Of course, intangible goods can be traded thanks to the tangible media on which they are recorded, but the copies (i.e., books, paintings, CDs) of these goods constitute a separate object of protection.

In making a distinction between copyright of creative work and rights to the thing, it is worth referring to the buying and selling process. The vast majority of transactions undertaken by users of 
creativity are limited to the 'ordinary' purchase and sale agreement of the 'recorded' medium. In this case, the use of the work does not require the acquisition of copyright (unless the use is commercial). The need to acquire copyright to a work mainly relates to the situation when the contracting authority/buyer wants to acquire certain rights in relation to the creative work and to obtain the status of the entity who can manage the work [34].

Translating this into the activities of museums and galleries of contemporary art: when buying a work for their collection, these institutions have first and foremost ownership of the medium. However, this is not tantamount to possessing property rights to this work. Meanwhile, it is the copyright status of a creative work that translates into the possibility of using a medium. The extent to which an institution will conduct its activities depends on the copyright status. And it concerns various types of activities such as exhibition, reproduction and dissemination for educational purposes, promotion, publishing activities [35] or digitization of collections. The activity of museums and galleries of contemporary works of art is of particular importance just because these institutions rarely have creative works in the public domain. This means that the legal status of works that are part of the collection sets limits in the implementation of tasks that have been entrusted to these institutions by law. This means that before a cultural institution undertakes any action to share an object from a collection or other acquired creative work, it must first regulate the legal issues.

The situation is slightly different in the case of creative works produced inside the organization. Examples of works created by employees of galleries and museums are, among others, publications prepared about the object from the collection, texts for exhibition catalogues, entries on institutions' social networking sites, descriptions and scenarios of exhibitions or museum lessons, graphic designs, visualizations and photo reports. If these works were created by employees as part of employee responsibilities, the institution acquires property rights on the basis of an employment contract. Therefore, there should be no problems with the legal status of these works. Nevertheless, contemporary galleries and museums make these works available to a wider audience to a limited extent. However, they are necessary to achieve the goal that the legislator imposed on them, in particular in the area of dissemination of cultural goods. An exception is, for instance, the Bunkier Sztuki Gallery of Contemporary Art in Krakow, which shares its educational materials developed by the gallery's employees, often on the occasion of exhibitions. They implemented a project entitled " $24 \mathrm{~h} \mathrm{Art",} \mathrm{under}$ which an educational portal was launched [36]. What is more, the content published on the portal has been made available under one of the Creative Commons licenses (attribution under the same conditions), which gives everyone extensive rights to use these works [37].

Based on the above arguments, it should be noted that copyright to works at the disposal of galleries or museums of modern art are essential for these institutions to be able to pursue their goals in the field of protection and sharing of collections without difficulties. Acquisition of copyright requires activity both in the field of re/negotiating contracts and in conducting legal status research. However, not every institution has a department for dealing with legal issues. Therefore, it seems important to develop a general framework for such actions as acquiring new works. How to implement open policy copyright management will be discussed below.

\subsection{Openness in Cultural Institutions}

Openness in cultural institutions can be considered in a narrower and broader sense. In the first case, an open cultural institution is one in which accessibility and the possibility of further use of resources under its care play a significant role. In a broader context, it is an innovative concept of using digital technologies to implement the institution's mission [6].

In accordance with the definition of the Open Knowledge Foundation, "open means anyone can freely access, use, modify and share for any purpose (subject, at most, to requirements that preserve provenance and openness)" [38]. This organization promotes free and open access to digital cultural heritage located in the resources of galleries, libraries, archives and museums. This initiative is called "Open GLAM" [39]. The term Open GLAM is associated first of all with a specific 
environment that promotes "openness" and, secondly, is understood as a kind of idea and attitude that encourages the openness of heritage resources. The word GLAM is an acronym for the names of cultural institutions-Galleries, Libraries, Archives and Museums-which is why we use it to refer to selected organizations.

An essential element of implementing an openness policy is the use of digital technologies and related communication channels [40]. Through the digitization of collections and open access to the Internet, the impact of cultural institutions is limitless. The need to digitize the European cultural heritage and the potential inherent in the standardization and transnational harmonization of digitization processes were quite early recognized by the EU, in particular the European Commission. On 1 June 2005, the European Commission adopted the "i2010: European Information Society" initiative [41]. In Poland, the resources of cultural institutions have been widely digitized and made available over the past few years, supported by nationwide programs, e.g., Culture + (2011-2015) or Digital Poland (2014-2020). Adopting an open policy, however, involves not only digitization for archiving purposes or the sharing of artistic works in the collection to the greatest extent possible. An open cultural institution also carries out its mission by encouraging recipients to engage in various ventures, participate in creative projects, and recommend valuable content.

In order to digitize and make works available online, a cultural institution needs to have the copyright for such activities. Research conducted in 2016-2018 by Centrum Cyfrowe (Digital Center) shows that among the most common legal doubts were: the lack of knowledge of authors and the inability to contact their heirs; digitized collections' placement in deposit that did not constitute the property of any institution; difficulty in determining material copyright (photographs are a special case); the general ambiguity of copyright law and the protection of personal and sensitive data [15]. These difficulties leave many valuable exhibits excluded from the digitization process. "Thus, public access to cultural resources is limited, which exhibition institutions, in accordance with their mission of collecting and sharing cultural heritage, should ensure" [42].

The facilitation of the digitization process occurs when the museum object belongs to the public domain. It means total freedom in sharing, translation, adaptation or remixing. Additionally, it does not matter if it is for commercial purposes or not. Moreover, it is not just that the rights are owned by the institution or the owner of the creative work, but by everyone. Going a step further, the idea of the open model follows the belief that cultural heritage is not the property of an institution but of a nation. Therefore, citizen rights to the culture they create should not be restricted. It is also not just about access digitized works or even "digital-born works", but also to descriptive metadata, bibliographic descriptions and catalogue data created by the employees of an institution, because without them heritage resources become useless for those who want to reuse them.

Knowing the legal status of collections, an institution can decide to make them available. The scope of sharing collections and the conditions under which they are made available largely depends on the policy adopted by the institution. Bearing in mind the statutory goals, institutions should aim to ensure the most open access to their collections. Open access should be understood as the lack of restrictions on the free use, reuse and further sharing of collections, with the possible requirement of invoking the author's name or sharing derivative works under the same conditions as the original. Open access to collections means the reduction of legal, economic and technical barriers to accessing and using these collections. Instead, open access must respect the law [42].

As the National Institute for Museums and Public Collections in Poland (NIMOZ) rightly notes, the collections of many Polish museums are wholly or almost wholly in the public domain [42]. Therefore, licensing should be avoided. However, you can mark such collections with a Public Domain Mark, which is a simple tool to mark a work for which there are no copyright restrictions [43]. The situation is slightly different in the case of resources that are still protected by copyright, such as works of contemporary art or employee creative works. Open sharing of these works requires licensing.

The most common first step toward openness is the use of free legal licenses: "Sharing content under free licenses means that everyone has the right to use, improve, adapt, reproduce, distribute 
for free or for a fee, and to disseminate their improvements so that the entire community can use them. The free license is one that granted to an unlimited number of people" [40]. Creative Commons licenses (CC) are a popular example that fulfills these conditions. It is an instrument that serves creators (or licensors) in managing the copyright of their works. These licenses allow the model of "All rights reserved" to be replaced by the "Some rights reserved" principle, while respecting the rules of copyright. In other words, the creator retains authorship rights and, at the same time, she/he allow others to copy and distribute her/his work. CC licenses offer a diverse set of license conditions: freedoms and restrictions. Thanks to this, the creator can independently define the rules by which they want to share their work with others. There are four license conditions, and six licenses are made out of them. The first of the conditions (Attribution; BY) occurs in every license and guarantees the protection of authorship. The second condition allows for the use of works only for non-commercial purposes (Noncommercial; NC). The third condition limits the creation of derivative works (ND). The last condition of "Share-Alike; SA" is a mechanism to support free culture and the popularization of free licenses [37,40]. The licenses have been developed to provide as simple and understandable legal conditions for recipients as possible. The cultural institutions implementing the policy of openness choose one or several (depending on the needs and type of available materials) from the licenses described above. The pyramid of openness (Figure 1) is helpful in ordering access levels and the freedom to use digital resources. At the top of the pyramid is the highest grade of openness and availability of resources. At the bottom we have a complete lack of openness and use.

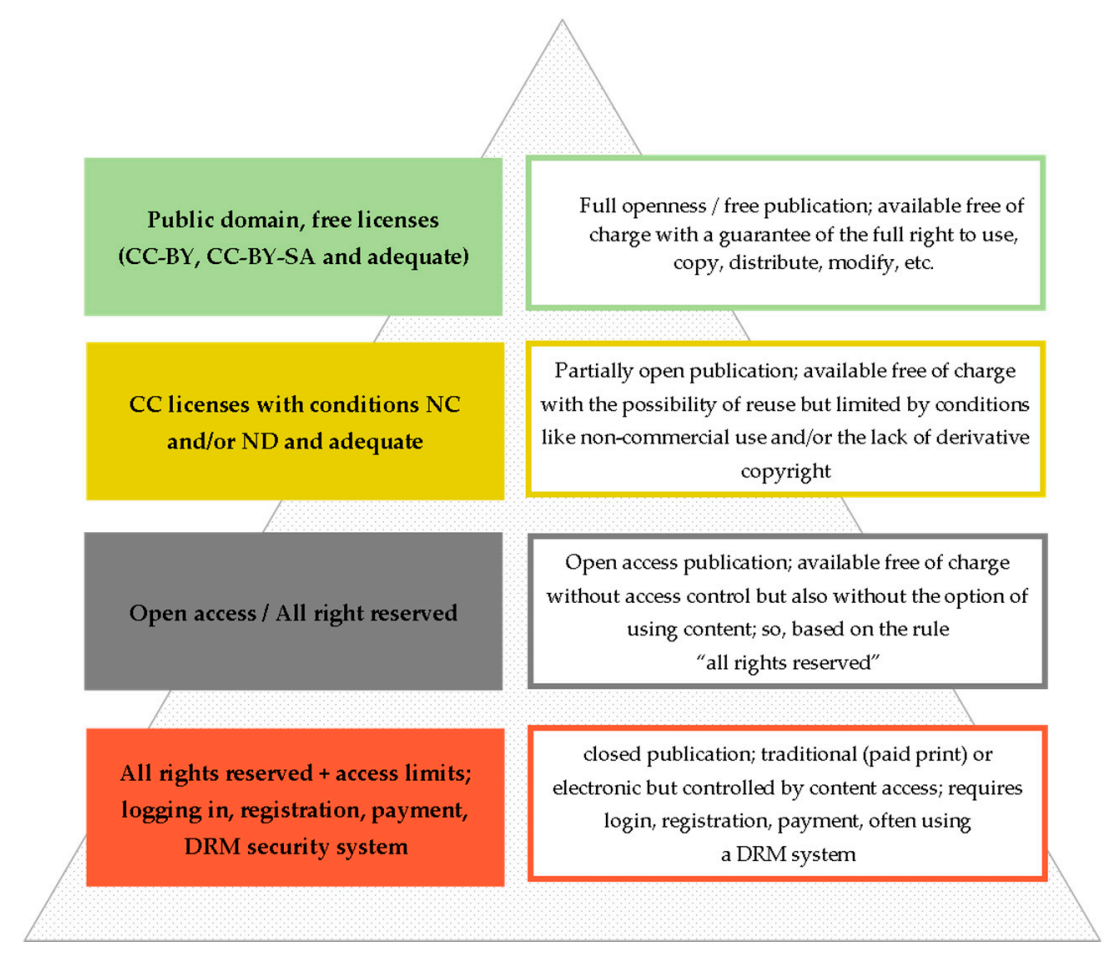

Figure 1. Openness pyramid based on the chart by Karolina Grodecka, available under license CC BY-SA [44].

The open resource model assumes significant changes in the way of thinking about the mission and functioning of contemporary cultural and heritage institutions. Although the dissemination of their collections and the accumulation of knowledge around them is an important element of the mission of public cultural institutions, the understanding of the social responsibilities of these institutions has changed significantly [7]. This is particularly important in the context of the changes that we observe in the way we define the role of the recipient (audience, user, public) in the Polish cultural sector. In front of our eyes, the audience is transformed into users, which requires the redefinition of 
the contemporary role of public cultural institutions. Therefore, we can observe a gradual shift in the accent from focusing on the collection to building relationships with recipients. This is accompanied by an increase in the interest in strategies for engaging audiences in the activities of cultural institutions (audience development, participatory models) $[8,9,45]$. These processes have their enthusiasts and critics, but the disputes and fears associated with them often relate to the legal and ethical limits of the use of cultural resources. This is accompanied by the-increasingly urgent-need to clarify what access (especially equal access) and openness mean, how to understand the sharing cultural resources today and how to treat their process of transformation (which ceased to be activities undertaken only by professional creators) [46]. Certainly, the large-scale digitization of heritage resources is an important starting point but, in practice, the lack of uniform standards for sharing digital resources stands in the way of those who want to make use of them [6]. As a consequence, institutions often treat the online publishing of collections as the final stage of the opening process, and the lack of guidelines on how to share results in leeway practices, including often publishing resources in low display resolution, with additional restrictions or without information about conditions of their possible use [6]. Current research also shows that the openness often seems to be an obscure and ambiguous term, and the feeling of the lack of specific guidelines and tools for their implementation results in discouragement or distrust [6].

No-one negates the need to adopt an open model in Polish cultural institutions. The Museum Development Strategy developed by NIMOZ in 2012 shows that "open access to museum collections in the so-called world of Web 2.0 is not only a duty to society but a necessity to raise key social competences, sustainable development, activate local community, raise interest in its own culture, support lifelong learning" [47]. But the process of opening cultural institutions is not easy. Research shows that the driving force of change is the human factor, i.e., the individual attitude of the management and employees of the institution to digitizing collections and sharing [15]. Adopting the right policy requires certain procedures, team support and the promotion of this policy. That is why intentional copyright management is so important, which I will discuss below.

\subsection{Copyright Management}

The main purpose for which copyright was created was to secure the livelihoods of creators and encourage them to continue their artistic work. On the other hand, the rational reason for which material copyright are limited in time is the interest of the general public and, indirectly, the creators themselves who, after all, do not work in a vacuum but use the work of their predecessors. While the interest of creators (and companies earning from the distribution of their work) is obvious-even countable into tangible amounts of money-social interest cannot be easily converted into specific values [48]. Referring to the above statements, the substantive starting point for further reflection is the belief that copyright for works is a specific challenge related to management, while public cultural institutions play a key role in this area.

Copyright management is a process in which owner rights generate a value based on the results of intellectual work. The main issue in the management process is the change of intellectual goods into financial results or other profits such as social relations, openness and cooperation. From the point of view of public cultural institutions, the essence of management is to coordinate the use of copyright on collections to achieve specific goals. It is this defined goal which provides guidance and gives direction to activities, inspires, motivates and fosters evaluation and review. The goal is formulated based on needs, expectations, ideals and values. It is also designated by the institution's, legally formulated, mission.

A sustainable approach to managing copyright to public collections of cultural institutions is a complex issue. For the successful functioning of culture, there is a need to create opportunities for legal mass access to intellectual property, while not discouraging creators from creative work. The trick is to allow recipients access to content without negotiations and individual contact with the author, but without depriving the creator of remuneration. In view of the above, it is crucial to formulate 
a copyright management policy following the recommendations of the international organization WIPO. Especially now, with the appearance of new technologies, there is a growing awareness of the importance of intellectual property and the role it plays in sharing knowledge, providing access to institution collections, and their protection and managing [16].

The policy on copyright in cultural institutions regulates the terms that an institution adopts to make its resources available. It works as a signal to recipients about the institution's mission and a signpost to the institution's employees when making intellectual property decisions. Intentional management of intellectual property consists of the adoption of appropriate legal, technical and communication solutions, taking into account the mission of the institution, the needs of the team and the effect that the institution wants to impress on recipients.

There are several reasons for developing internal copyright rules for collections of cultural institutions. First, adopting copyright management policy reduces the risk of infringement. The strategic approach to managing intangible goods owned by the institution also allows for the assessment of potential opportunities for the implementation of the institution's mission. A coherent way of making decisions in this area ensures quality throughout the organization, while the adopted principles guarantee that decisions will be made consistently by using the same set of standards. Last but not least, thanks to the formulated copyright management policy, recipients see clear rules for using the collections, which contributes to the exploitation of resources and educational activities [16].

Copyright policy is not a finished product. How it should look and how it should be implemented depends on the institution itself; its mission and its team's expectations. The implementation phase requires not only the development of the policy text but also the procedures for how it will be implemented. It is also necessary to support the team, which may have to be assisted by additional training or consultations. The implemented policy of openness should also be promoted among recipients, because only thanks to this they will know how using heritage is possible and in accordance with the law. The intentional management of copyright should also include an evaluation process: the internal evaluation of implementation, the environmental impact of policy study, the potential supplementation of procedures and further support of the implementation process [49].

In Poland, there are few institutions that have a policy for managing the copyright of their resources. What certainly deserves attention is the Polish History Museum (PHM) in Warsaw. The institution was established on May 2, 2006, as a state cultural institution. The museum has no headquarters (the permanent headquarters of PHM are under construction on the site of the Warsaw Citadel) and is in the process of building its collection. Currently, it focuses on organizing temporary and online exhibitions. The PHM stands out from others because in the first years of its existence it has already developed a document that sets out the rules and principles on which it acquires rights to works and how it makes them available to recipients. In cooperation with Centrum Cyfrowe and Creative Commons Poland, after a study among employees and recipients, a Declaration of the PHM Openness Policy was formulated [50]. It shows that all works within the framework of exhibition, scientific and educational activities will be freely available, if possible, without economic and technical barriers, using for this purpose open and free Creative Commons licenses. The declaration concerns resources owned by the PHM but also those created or funded by the institution.

By adopting the Declaration, the PHM ensured that all digital copies of works for which copyright had expired would be correctly marked as belonging to the public domain (with the Public Domain Mark [43]). Digital information about the works available in digital form as part of exhibition activities (metadata) will also be transferred by the PHM to the public domain thanks to the possibility of using Creative Commons 0 statements [51]. In addition, educational, scientific and popularizing materials which are the subject of copyright are, as far as possible, published under open CC licenses [50]. As a consequence of the copyright management policy adopted in this way, the PHM published under free licenses, among other things, educational materials and scripts for history lessons, scientific articles and publications, on the BazHum website-a bibliographic database of humanities and social sciences journals - and as content on the website with antique prints of the History Institute of the 
Warsaw University. The PHM also stipulates the right to openness in its competitions and scholarship program [52].

The PHM in the field of copyright management policy should be assessed positively due to the systematic, structured and consistent operation of all departments of the institution in order to standardize the rules for signing contracts and obtaining copyright for works. It is also worth mentioning, however, that the vast majority of the collections are not subject to copyright protection and are in the public domain. The institutions that have been operating for many years without copyright management policy are in a much more complicated situation. What is more, they manage creative works for which the copyright has not yet expired. Museums and galleries of modern art are in this special situation. The implementation of copyright management policy in such institutions is burdened with much greater risks. Therefore, in the latter part of the work, I will focus on these institutions.

\section{Materials and Methods}

The research problem that I seek to solve concerns the subject of copyright management in exhibition institutions in Poland. The starting point to the reflection is the conviction that copyright for a collection is an indispensable resource enabling the implementation of the mission of museums and galleries. The mission of cultural institutions is an expression of sustainable development, which assumes a specific paradigm of social order based on respect for the right of access to culture, in accordance with the principle of openness and care for the common good which is cultural heritage, in order to preserve it for future generations. The key question I have tried to answer is:

How should public exhibition institutions in Poland manage the copyright of collections to achieve their mission in a sustainable way?

To answer the above question, I used a case study to illustrate the problem. There is no single binding definition for this research strategy. Robert K. Yin defines the case study research method "as an empirical inquiry that investigates a contemporary phenomenon within its real-life context" [53]. However, according to Robert E. Stake, case study research is "the study of the particularity and complexity of a single case, coming to understand its activity within important circumstances" [54]. There are also different typologies of case studies in the literature. One of the most popular is the one proposed by Robert E. Stake, who distinguishes intrinsic case studies, collective case studies and instrumental case studies [55]. Here, I follow the latter, as the case has an auxiliary role and facilitates the understanding of the studied issue.

According to Nicolaj Siggelkow, case studies can reveal the significance of a specified phenomenon in a more convincing way than theory. What is more, they can be an inspiration for new ideas and an introduction to the study of phenomena that do not have a sufficiently developed theoretical background. An interesting way to use a defined case is to also use it as an illustration, which will help to stimulate the reader's imagination and facilitate the understanding of theory [56]. Guided by these considerations, I chose as a case study the Zachęta National Art Gallery in Warsaw, a state-owned cultural institution that has been implementing a copyright management policy since 2011, inscribed in the foundation of the project called "Open Zacheta". The selection of the example is intentional. The key is that Zacheta's collections mainly contain works of modern art, which means that the copyright to most of them has not expired yet. Therefore, the need to manage intangible goods comes to the fore, in such a way that the institution can fully implement its mission.

To solve the formulated research problem, based on the selected case study, I formulated the following leading questions:

What organizational and legal changes were (and are) introduced in the Zachęta National Gallery of Art to respond to the social need for open access to cultural goods? What are the benefits of these changes? What are the barriers to managing copyright that hinder the sustainable implementation of Zachęta's mission? 
In order to collect data, various research techniques were used, i.e., interview, observation, survey, analysis of texts and found content. In order to obtain information from the organizations, a standardized unstructured interview was conducted with an employee of the collection and inventory department from the Zachęta National Gallery of Art; that is, with a person who from the very beginning was involved in the implementation of the open policy copyright management. The interview was carried out remotely in April 2020 (via e-mail) and the questions were of an open nature, so that the interlocutor could answer freely and in any form. Literal statements of the interlocutor will be marked with the letter $(\mathrm{W})$.

Zachęta during the implementation of the open policy has conducted promotional activities from the very beginning. As part of these activities, numerous articles have been published on the institution's website, which have been reviewed. In addition, the recordings of interviews and interviews available in printed publications with the director of Zachęta, Hanna Wróblewska, were analyzed.

Furthermore, on January 10,2020, a study visit to the institution took place, during which-together with 32 students of the Jagiellonian University-I had the opportunity to talk to employees of various departments: education department, collection and inventory department, as well as with the assistant of the exhibition curator and the person from the accessibility team. Moreover, I had the opportunity to observe the work of the educator who was conducting the workshop and was using tools available under free licenses. The observation was non-participating; during the observation I kept notes. After this meeting, students prepared written essays assessing the process of openness policy implementation in Zacheta. In total, I collected 32 essays that were analyzed and treated as the point of view of an objective recipient. Literal students quotes are marked with the letter (S).

The most difficult stage of the research process was obtaining contact details from the creators with whom Zachęta signed copyright agreements using CC licenses. Due to the numerous restrictions linked with the Covid-19 pandemic, I finally decided to conduct a short online survey consisting of five open questions (see Appendix A) to allow creators to submit a free answer. The survey was sent to 30 creators and was available for completion from March 22 to April 16, 2020. Five artists answered: Radek Szlaga, Iza Tarasewicz, Rafał Jakubowicz, Zuzanna Janin and Bogna Burska.

\section{Results}

\subsection{The Mission of the Zachęta National Gallery of Art}

The Zachęta National Gallery of Art began its activity in 1860 when the Society for Encouragement (Polish: 'Zachęta') of Fine Arts was established on the initiative of painters. Since the onset, Zachęta was a social and national initiative. Thanks to numerous donors, it was possible to build an impressive institution headquarters, which was opened on 15 December 1900. An important part of Zachęta's activity was to create a collection of Polish art thanks to purchases and gifts. After the Second World War, the Central Office of Art Exhibitions was established in the Zachęta building, which was turned into a state gallery after the transition from the Communist system and, following that, into a national gallery. It has operates as the Zachęta National Art Gallery since 2003. It is a place where the most interesting phenomena in 20th and 21st century art are presented [57].

According to the statute, Zacheta's mission "is to promote contemporary art in all its current manifestations, treated as an important element of culture and social life" [58]. Dissemination, being the social mission of Zachęta, is understood as facilitating contact with contemporary art from various milieux and groups. The Director of Zachęta, Hanna Wróblewska, adds: "Our mission has not changed from the beginning .... And we certainly don't want to change it. We can call it differently at different times. Once we talk about propagation, once about promotion, but it always means the same: dissemination" [59].

One of Zachęta's key tasks is to organize exhibitions and artistic events. Zachęta has no permanent exhibition, it only organizes temporary exhibitions. Part of the works created by artists for particular exhibitions goes to the Zachęta collection. Zachęta also conducts educational activities targeted at 
various audiences, publishes books on contemporary art and gathers information on Polish artistic life after 1945. It also supports the most interesting phenomena in contemporary art and culture through the implementation of artistic projects and the promotion of artists and events. An important task entrusted to Zacheta is the organization of presentations in the Polish Pavilion at the International Art Exhibition and the International Architecture Exhibition in Venice, one of the world's most important art festivals [57].

A certain characteristic feature of the institution is that Zacheta's resources include works of contemporary art. Statistics provided by the institution show that all the works-and there are 3676 of them-are still under copyright protection (70 years have not passed since the death of the creators), which in practice means that with the purchase of a copy of an artwork there are legal restrictions to its use. Therefore, in order to implement its social mission of dissemination, Zachęta must employ the planned management of copyright.

\subsection{Open Zachęta}

In 2011, Zachęta began a process of change by implementing the Open Zachęta project, "whose purpose is to make collections much more available to the public" [59]. Openness is understood by its employees broadly, because it concerns, among other things, digitization, sharing Zachęta collections, building accessibility, education and openness to groups so far excluded. Therefore, it is about opening Zachęta from the physical, technical and digital side. However, due to the subject of the article, only selected issues will be discussed.

Within the framework of the adopted policy, Zacheta should be a place open to everyone and open on everyone: "The institution is guided by the belief that 'opening' is a way to disseminate art, to facilitate access to it" (W). The director of Zachęta notes that a great tool facilitating the implementation of Zachęta's mission today is digitization and the digital world. As she explains, "of course, contact with art via a computer should not be equated with a visit to the gallery, but both forms of dissemination can complement each other" [59]. In her opinion, sharing collections and information online influences participation in culture, because it also gives a chance to access culture to people who would be unable to do so [60].

The second important issue raised in the conversation is that Zachęta, a national institution, was guided from the beginning by the slogan, "what is created with public money is public property" (W). Opening the gallery's resources is treated as a response to this, while implementing heritage protection and care. In one of the interviews, Hanna Wróblewska said:

"In Poland, the neoliberal view of culture is still widespread, which sees in the assets of cultural institutions wealth and sources of potential material gains. This approach assumes that public institutions should not only live off their resources but also earn (only) from them ... . I do not believe that the potential financial influences from 'closing collections' would balance the non-financial benefits of openness policy! Not in the case of Zachęta, whose mission-inscribed in the statute-is to disseminate! ... Since public institutions are financed from public funds, their purpose is not to earn or balance, but to provide content" [61].

The person who showed me this interview argued that the decision to implement the openness policy was also influenced by the specifics of Zachęta's activities. As I mentioned above, only temporary exhibitions are organized, there is no permanent exhibition of the collection. "This means that the works owned by the institution spend most of their time in warehouse. Instead, their online presentation gives them a 'second life'" (W).

My interlocutor claims that "the impulse to introduce the policy of openness in Zacheta came 'from a high position', that is from the management who heard about and became interested in the Open GLAM movement" (W). However, what is interesting is Hanna Wróblewska's 2013 statement:

"The great strength of this project was that it worked on the level of employees themselves.

They came up with it, it was their idea. We met together and I didn't have to demand 
anything. Because, in my opinion, it is very difficult to demand openness; either a person feels open and wants to be open, or he or she finds one thousand five hundred right truths and reasons for which you cannot be open in the cultural institution, even if you want to" [60].

These statements show that both employees and management wanted to implement an openness policy. First of all, the management offered two employees from various departments (including my interlocutor) training organized by the Coalition for Open Education (KOED). The training concerned the idea of Open GLAM and the use of free Creative Commons licenses. Following that, there was a series of meetings with other employees and consultations with lawyers. A project group was also established because interdepartmental cooperation was paramount.

The key decision taken by Zacheta was to choose the right tool with which its resources were to be made available: "Creative Commons licenses have been chosen because they are the most popular, the most accessible to use and allow different degrees of openness" (W). The employees underwent appropriate training organized by Centrum Cyfrowe, which was dedicated to the practical use of CC licenses, aimed at preparing for the implementation of openness in the institution. In the process of developing the policy of openness, it was decided that all of Zachęta's resources would be made available to recipients as widely as possible, i.e., not only images of the work from the collection but also documentary materials (e.g., films from exhibitions, catalogues, folders), educational materials (workshop conspectus) and other publications (e.g., texts/articles, audio descriptions). Hanna Wróblewska talked about the idea in 2011:

"We do not want to be seen only as a 'machine for making exhibitions' or creating symbolic capital and setting new canons. We want to be an open institution, as our entire activity stands in front of the public. Zachęta believes that some of our works should be available under free licenses. It is also the result of our thinking about facilitating access to this content to recipients also from outside of Warsaw" [61].

The implementation of the adopted copyright management policy was of a two-fold nature. First of all, looking to the future, it was decided that for everything that will be ordered, bought, or obtained from 2011 onward, CC license will be implemented at the initial stage of negotiating contracts. On the other hand, there began the time-consuming process of "opening" resources already in the institution's collection, while verifying the rights to these works [57]. The consequence of the Open Zachetta project's implementation was the creation of the otwartazacheta.pl and then zacheta.art.pl portals, in which all 'released' resources are published, not just those in the collection. Digitized works are made available in high resolution. Some of them have been added to Wikipedia. Each of the shared works is clearly marked with the name of the CC license so that users have no doubts about their powers. Zacheta's statistics show that a total of 1400 works have been digitized so far, of which about 350 have been made available under free licenses (CC BY-SA).

Teachers are an important group with which Zachęta cooperates. Zachęta organizes a series of (cyclical) training sessions and workshops, during which an important element is to inform about both the institution's open resources and generally about the phenomenon of Open GLAM. The institution also encourages teachers to use materials under free licenses and to create similar works themselves.

According to employees, the implementation of openness has many benefits for the institution itself. Apart from this basic element related to the implementation of the social mission (referred above), the benefits are promotional issues: "resources are more easily available and usable, so their reach is broader" (W). The institution tries to emphasize the openness policy, e.g., in cooperation with entities such as publishers or employees of other institutions. Some of them know about the available resources and use them, marking the author and source, which also has a promotional benefit for Zachęta.

Another benefit resulting from the choice of openness is that of image promotion. Presented as an example of an open institution in the media, Zachęta received the award "Guarantee of Culture" 
granted by TVP Kultura a few years ago. Moreover, the interlocutor confirmed that open resources facilitate daily work:

"If someone is interested in using, for example, reproductions of a work from our collection, I show them to our website with information that they can download a photo. I do not have to sign a complicated license agreement with them to allow the use. Open resources also help our education department in creating materials, in cooperation with teachers, the publishing department in preparing publications" (W).

Research shows that the basic difficulty in implementing an 'open' copyright management policy is the unregulated copyright of many resources. "The oldest objects from the Gallery's collection come from the 1920s, most come from the 1960s to 1980s. Even having rights to them, contracts don't cover new fields of exploitation, such as the Internet" [61]. In addition, "in connection with the history of the institution and the specifics of its activities during the period of the Central Office of Art Exhibitions, a number of works from this period, which are included in our collection, do not have the documents needed for sharing in accordance with current regulations" (W). "Digital works, such as film or photography, are also a difficult issue, in which the distinction between the original and the copies are arbitrary and, furthermore, these works appear in editions" (W). It is not always possible to contact heirs, and Zachęta does not have employees specifically delegated to such work. Moreover, a lot of workload requires convincing creators and heirs to share works on free or more open CC licenses. However, I will discuss this topic below.

In the initial phase of implementing the policy of openness, the institution also encountered problems related to infrastructure, "which in Zachęta was created for years without special finances and, therefore, out of necessity, without a broader plan" [61]. Sharing content online required the creation of a special platform because the computer system at the time would not have been able to support such software. Financial barriers are also associated with the digitization process. Zachęta does not have a digitizing studio and it commissions work externally.

The implementation of an openness policy required the employees to change certain habits, which was not always easy. As all resources on free licenses are sent to the online platform, employees had to develop a system for preparing and sharing materials. Many people also had to switch and learn to include CC licenses in contracts. "Initially, this caused some difficulties but, over time, it became a habit" (W).

Many assess positively Zachęta's activities towards implementing the policy of openness. This is evidenced by written papers prepared by students of the Jagiellonian University. Students paid particular attention to the fact that the digitization and dissemination of works in the digital space "allows for the collection to be revived, instead of remaining inaccessible in a warehouse" (S_01). They were convinced by the idea of sharing works under free licenses, agreeing that such legal facilities improve the circulation of culture. They also appreciated the organizational effort that Zacheta has made. They were very impressed that the activities are well-coordinated and cover the entire organization. Criticism, however, concerned two aspects: technological solutions and promotion.

Students evaluated negatively the portal containing digitized works, indicating that it is not easy to use or clearly presented. They also argued that it would not seem obvious to the average recipient that there is an option of downloading a file from the site and using the work while respecting copyright. One student wrote: "the digital distribution of the collection gives the impression of being created for the idea itself rather than for the actual promotion of modern art or to facilitate access to the collection. There is no proper publicizing of this initiative, which after all would not be a barefaced advertisement of the institution itself, as a real extension of the statutory activity" (S_02). Students pointed out that, although the name of the license and the permission to use the collections appear next to the works, no educational actions are directed to the average recipient as to what specific licenses mean and what rights they give to users. There is information about the license available on the Zacheta website but not directly next to the creative works. Sometimes they regret that actions 
encouraging the use of works are targeted only at professional recipients, such as teachers, and not ordinary users; as one student summarized: "it builds an illusion that art may and is available, but not needed by anyone, who doesn't write lesson plans" (S_03).

\subsection{Creators Cooperating with the Zachęta National Gallery of Art}

We read on the Zacheta website that, "as a contemporary art gallery, we deal with works that will pass into the public domain only decades from now. The artists and authors we work with have their reasons, reservations and fears. To address them, we conduct the broadest dialogue possible, trying to convince artists to embrace CC licenses by presenting their advantages and benefits" [62]. In practice, first of all, by purchasing a copy of the work, Zacheta seeks to acquire the copyright to the widest extent possible at various fields of exploitation, including the right to create dependent works (adaptations, remakes, translations). In addition, Zachęta negotiates with authors that in the event of new fields of exploitation of the work (unknown at the time of signing the contract), they will be obliged to transfer their rights to the institution as part of the remuneration received on the basis of the original signed contract. This approach eliminates the difficulties encountered by cultural institutions that wish to digitize works and have no rights to such use of an artwork. This action protects the institution against possible legal impediments in the implementation of the dissemination mission. In addition, Zacheta encourages creators to make available to third parties reproductions of the work under a Creative Commons license in the version: attribution under the same conditions 4.0 (CC BY-SA) [37]. The terms of this license allow users to copy and distribute works in any medium and format, and allow the remixing, change and creation based on the original work, including for commercial use. The user must, however, meet two criteria. First, the work should be accordingly marked, provided with a link to the license and an indication of any changes that have been made to it. Secondly, when processing or creating a work, the newly created work should be distributed under the same license as the original.

After hearing the terms of the contracts offered by Zachęta, I was interested in how the creators approach the idea of sharing their works using CC licenses on the institution's platform. My interlocutor states: "Of course, we deal with the whole spectrum of approaches to free culture. However, trust in us and our actions prevails. I do not keep statistics, but I can say that most creators agree to the proposed conditions (some simply do not attach much importance to this, while others are satisfied with this policy)" (W).

She adds that the situation looks slightly different in the case of resources produced, ordered or purchased by Zachęta and differently when borrowing works for exhibitions. In the latter case, there are more situations in which the owner does not agree to CC licenses, because they are engaged in commercial activities related to reproductions. Hanna Wróblewska states: “We don't want to force anything on anyone. We know that the material situation of visual artists in Poland is often not good. We have obligations to them, because the art market remains weak" [61]. "Agreements are signed with artists and authors based on choice. We say that we are a public institution, we publish on such licenses. However, if the person says no, they have every right to do so" [60]. "Open licenses cannot be seen as a pressure apparatus. The libertarian regime cannot be the answer to the patent regime" [61].

According to the statements of Zacheta employees, the youngest artists are very enthusiastic about openness. Artists of the older generation have more concerns, which are primarily related to the preservation of the integrity of their work [61], i.e., that the work may be used or modified in a way inappropriate or inconsistent with the author's intention. Commercial issues also occur, but these tend to be secondary. Zacheta ensures that it is open to compromise when creators are not convinced of the adopted policy, while consistently keeping with Creative Commons licenses. Instead, it introduces possible restrictions, such as non-commercial use or disagreement with the creation of derivative works.

In talks with artists, Zacheta makes them aware of the policy of openness. Referring to the mission of a public institution, employees explain why Zachęta wants to make all resources available as widely 
as possible. They also show the promotional benefits of sharing creative works. They explain that CC licenses guarantee authorship. They argue that sharing purchased collections under a CC license is, in a sense, a way to give back copyright to the creators of these works. In other words, the creator, like other users, can still use the work freely, although the work was bought by Zachęta. An important issue was raised by my interlocutor:

"The implementation of free licenses made us realize how little awareness do authors have about copyright. However, this has changed in recent years. There is also a growing awareness of the general change in the use of culture in connection with the 'Internet revolution'. More and more people are realizing that it is hard to avoid the free flow of content online, and even that it is difficult to exist without taking part in this flow. It is for the benefit of all to release own content and, thus, care for its quality" (W).

I wanted to confront the statements received after interviewing and analyzing the available information with the opinion of artists. This was not an easy task, but I managed to receive the opinions of five people: Radek Szlaga, Iza Tarasewicz, Rafał Jakubowicz, Zuzanna Janin and Bogna Burska. Because of the small research sample, the results of these studies cannot be generalized. However, the obtained knowledge provides important information that allows at least a partial assessment of Zachęta's activities.

The research shows that the creators do not pay too much attention to the conditions of sharing their works. Only one person was able to provide the name of the CC license. These data are available on the Zacheta website and after checking it turned out that two creators had shared their works on the Zacheta platform under the most open CC license offered by the institution, namely, Attribution Under the same conditions (CC BY-SA). Other authors made their works available under the least open CC license: Attribution-Noncommercial Use-No Derivative Works (CC BY-NC-ND).

The reasons for sharing works under a free license were similar. The creators argued that art should be available, especially if the work goes to the collection of a public institution. Radek Szlaga pointed out that "he does not create only for himself, he wants his voice to be heard and the platform allows him to reach the recipient". Only one of the creators stated that "the work went to the Zacheta collection and the decision to share the work on free licenses is a decision of the institution", not creator. However, this statement may indicate that the creator is unaware of the copyright law.

None of the artists were afraid of sharing works under the CC license. Among the main-or, in fact, the only—advantages of sharing works were measurable benefits of popularizing art.

\section{Discussion}

The study shows that in wanting to carry out its mission in a sustainable way, the Zachęta National Gallery of Art decided to implement an open policy of managing copyright. The institution's mission is to ensure as broad as possible access to culture. It was recognized that in the face of ongoing changes in the world, the manner of implementing public institutions' missions should also be different. These changes are briefly described by Justyna Hofmolk, Alek Tarkowski and Kamil Śliwowski:

"The cultural landscape has changed dramatically. Still in the mid-1990s, participation in culture was mostly associated with either mass media or cultural institutions. In less than two decades, competition has appeared in the form of cultural content circulation and spaces of cultural activity related to the Internet. Today, the Internet is a source of content, including content unavailable on television or in the library. The network is also a space for own, individual or collective activity related to creating, recommending or sharing resources" [40].

The Zachęta National Art Gallery decided that in order to fully realize its mission, i.e., provide access to culture, promote cultural activity and care of a shared heritage, it needs an open copyright management policy that makes maximum use of new digital technologies and related channels of communication. It assumed that the use of open licensing models will favor openness. 
The process of introducing changes turned out to be a long-term activity, requiring the involvement of all employees of various departments. After all, engaged employees are those who are convinced of the idea of openness. Research shows that there was no objection to changes in Zachęta, but to facilitate the implementation process, employees were supported by appropriate training sessions and workshops. Cooperation with external organizations and individuals (including lawyers) with knowledge about open licenses and the open GLAM movement proved helpful. The following organizations in Poland deserve special mention: Centrum Cyfrowe Projekt: Polska [63], which implements the "Open Culture" program; the Coalition for Open Education [64], which supports the creation of open cultural resources and promotes good practices and related tools; and CC Poland, one of the branches of the American Creative Commons organization [65].

The implementation process of Zachęta's open copyright management policy consisted of several stages. The most important activities included:

- the choice of the right legal tool (in this case, a CC license);

- the organization of meetings, workshops and training sessions devoted to the practical use of CC licenses and the idea of open GLAM;

- the creation of a project group consisting of people from various departments;

- the mapping of resources and opportunities, along with potential problems;

- consultations with external organizations and lawyers;

- the establishment of rules for sharing resources;

- the development of model contracts;

- the negotiation and renegotiation of contracts with creators and heirs;

- the digitization of works in the collection;

- the creation of a portal enabling the publishing of 'released' resources;

- the promotion of openness.

The implementation of an open policy copyright management will not happen overnight. In the case of Zachęta, however, it turned out to be helpful to set a border point that from that moment the institution is trying to make available what it acquires or what will arise under free licenses. At the same time, Zachęta is slowly renegotiating past contracts. In my opinion, this is very important because if the institution began its activities from the inventory, it would take too much time until it was finally possible to achieve its goal. Such action could be too frustrating, employees would burn out and it would not be possible for openness policies to be implemented.

The key benefits of the institution's 'open' approach to copyright include not only the basic ones related to the implementation of the mission, but also promotional and image benefits. The benefits are also pragmatic because they facilitate daily work in the institution, according to the same set of standards. Thanks to the adopted policy, clear rules are also formulated for users who want to use the works without infringing on copyright.

The biggest barrier to copyright management that hinders the institution's mission in a sustainable manner is insufficient attention to copyright as an institution's important intellectual resource. This problem intensifies when the institution has several years of tradition and most of the works in the collection have not yet entered the public domain. Such an example is Zachęta, which has in its collection many works with unregulated copyright and legal specifics. This is difficult to amend immediately, especially since Zachęta does not have a person specifically delegated to this task. This is not an isolated problem either. As NIMOZ points out, the optimal situation would be to create a legal unit in every institution but, unfortunately, this is not always possible [42].

The Zachęta National Gallery of Art is a specific public organization in Poland which was one of the first institutions to adopt an open copyright management policy. Among museums and galleries of contemporary art, it is difficult to find an institution like Zacheta that would approach copyright management in a coherent and holistic manner. However, it is worth mentioning, for example, the Contemporary Art Gallery - Bunkier Sztuki, which provides numerous educational materials on 
free licenses. The Museum of Art in Lodz has also started to digitize resources of old art (because they also have them in their collection). However, these activities are selective and not related to the implemented policy of copyright management. Therefore, it appears that other institutions can learn and diagnose problems based on Zachetta's long-term experience. In particular, learning that the copyright management process is ongoing. It requires changes in the organization, but also time-consuming actions to convince creators (and heirs) to the idea of openness. Promotion is also needed to encourage the community to use shared works. However, the example of Zacheta shows that it is not possible to prepare a single universal strategy. The policy of open copyright management depends on the mission of the institution, the needs of the team but also the effect that they want to achieve for the recipients. Museums and galleries of modern art are in a special situation, as copyright for them is a key resource that allows—or disallows—-the dissemination of resources.

\section{Final Conclusions}

When performing their statutory functions, museums and galleries operate in a given social environment. The legislator imposes on them socially useful goals and tasks related to protecting and disseminating. At this point, a reference to classic management texts may seem interesting. As Andrzej K. Koźmiński writes, "it is undisputed that the most general goal of all organizations is survival and development" [66]. Referring this statement to the public missions of museums and galleries expressed in law, the first goal, to survive, is achieved through the protection and conservation of resources in the collection. In turn, development requires the guarantees of full, equal and unrestricted access to cultural goods. Moreover, none of these goals can be considered more important than others. Meanwhile, as Łukasz Gaweł notes, "since we began to perceive monuments as valuable memorabilia of the past, we have obsessively focused on their conservation and protection" [67] (p. 15). However, a modern approach to management in culture can only be achieved by finding a balance between these goals. Heritage should be managed skillfully for the public good.

In this paper, I focus on describing dissemination activities carried out by public cultural institutions. I tried to prove that the necessary resource, which is not only the facilitation but above all the enabling of the sharing of cultural goods-and thus the implementation of the institution's mission-is the copyright to the collection. This particularly applies to museums and galleries of contemporary art, which have works still protected by copyright in their collections.

Public institutions that wish to implement their mission in a sustainable manner should undertake the effort of managing copyright. The purpose of this article was to try to answer the question: how to manage these rights? Analyzing the results of the conducted research, using the example of the Zachęta National Gallery of Art, we should assume that copyright management requires a well-thought-out, coordinated and planned action. Institutions should begin by developing appropriate legal and technical solutions to facilitate the sharing of own collections, seeking to democratize access to cultural heritage. The adoption of such a policy requires the involvement of almost the entire organization because regulating the rules should be consistent not only with the mission of the institution, but also with the needs of the team. In the context of the discussed case, the positive attitude of the management and regular employees to the idea of openness, jointly agreed upon, turned out to be particularly helpful. The advantages of openness, barriers to implementation of openness policy and recommendations for how to implement the described approach are summarized in Figure 2. Based on this example of Zachęta, we should state that the human factor, adopted values and ideals have become the measure of success. 


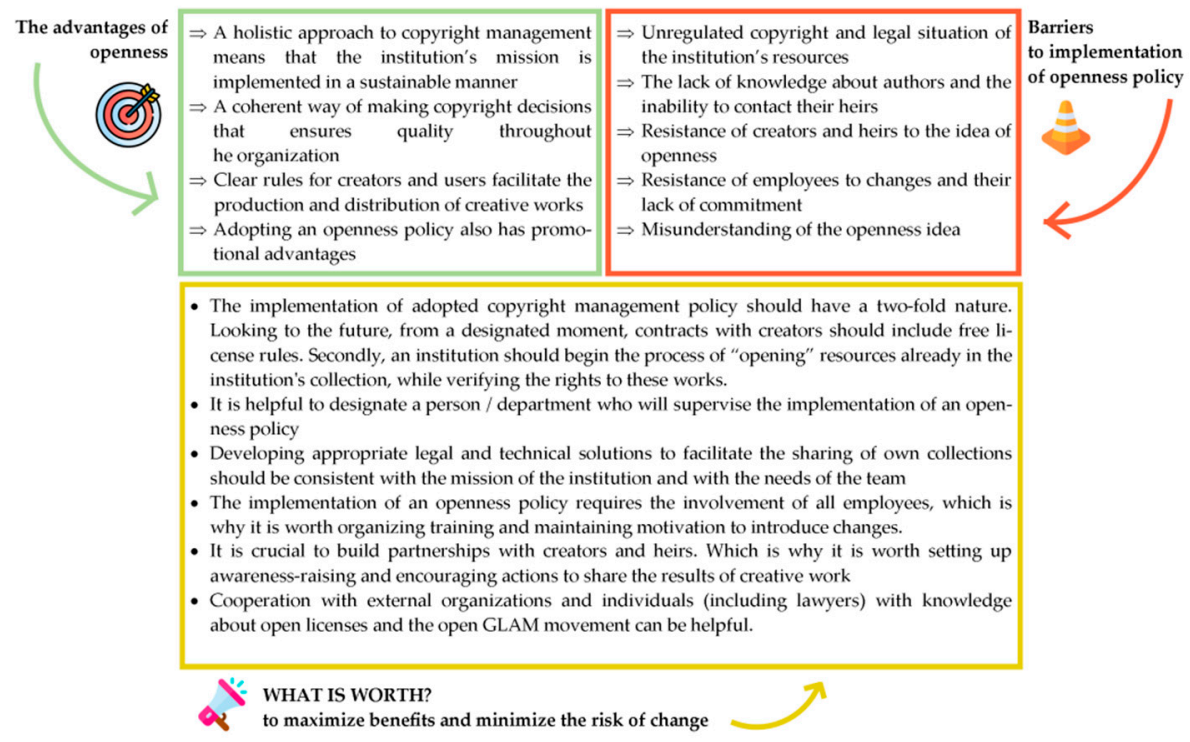

Figure 2. Open policy of copyright management.

An important issue in implementing copyright management policy is also building partner relationships with creators. The realization of any adopted strategy would not have been possible without their agreement. A cultural institution plays a special role, so when it wants to share its collections, it cannot do so at the 'expense' of the creators. It should, therefore, set up awareness-raising and encouraging actions to share the results of creative work. This task seems particularly difficult because it requires some sensitivity to the needs and fears of artists.

The above statement indicates one more major issue, important for the copyright management process. Both in the literature $[5,67]$ and as a result of research [6], there appears an argument that the collection, which is a piece of cultural heritage, is not the exclusive property of the public institution but a common good; therefore, it should be made available as widely as possible. However, it seems that these arguments appear in the context of collections that have a material nature. Copyright is an intangible resource, so it becomes a common good only when it belongs to the public domain. This means that due to copyright restrictions, collections of museums and galleries of contemporary art cannot fully become public goods. That is why actions promoting openness among creators are so important.

Due to the diversity of cultural institutions and their resources, it seems impossible to give a precise answer to the following question: how should public exhibition institutions manage the copyright of collections to achieve their mission in a sustainable way? The research carried out at Zacheta only allowed to present examples of ways of acting that can be an inspiration for other exhibition institutions. What can be concluded from this study is that the copyright to the public collection of a cultural institution must be managed. The assumption of this process is a conscious, responsible and thoughtful (based on reliable knowledge about the ownership of intangible resources) decision, regarding access to cultural goods in such a way as to make the most of the wealth of public goods entrusted to public institutions.

Funding: This research received no external funding.

Acknowledgments: Thanks to the Zachęta National Gallery of Art for the opportunity to carry out the research.

Conflicts of Interest: The author declares no conflict of interest.

\section{Appendix A. The Questionnaire}

1. Your works are in the Zachęta National Art Gallery collection. They have been made available on the institution's platform under one of the Creative Commons licenses. Which licenses? 
2. What made you share your works under a free license on Zachęta's platform?

3. Did you have any concerns about sharing your works under a free license? If so, what kind of concerns were they, and did they come true in retrospect?

4. Do you think that sharing works under a free license by a public cultural institution such as Zachęta brings any benefits for the creators? If so, what kind of benefits?

\section{References}

1. Hawkes, J. The Fourth Pillar of Sustainability: Culture's Essential Role in Public Planning; Common Ground: Melbourne, Australia, 2001.

2. World Commission on Environment and Development. Our Common Future; Oxford University Press: New York, NY, USA, 1987.

3. Golat, R. Podstawy Prawa Kultury; Wydawnictwo Poznańskie: Poznan, Poland, 2006.

4. Lessig, L. The Future of Ideas: The Fate of the Commons in a Connected World; Random House: New York, NY, USA, 2001; ISBN 978-0-375-50578-2.

5. Sanderhoff, M. Foreword. In Sharing is Caring. Openness and Sharing in the Cultural Heritage Sector; Sandehoff, M., Ed.; Statens Museum for Kunst: Copenhagen, Denmark, 2014.

6. Buchner, A.; Janus, A.; Kawęcka, D.; Zaniewska, K. Otwartość w Instytucjach Kultury. Raport z Badań; Centrum Cyfrowe Projekt Polska: Warsaw, Poland, 2015.

7. Van Mensch, P. Museology and management: Enemies or friends? Current tendencies in theoretical museology and museum management in Europe. In Museum Management in the 21st Century; Mizushima, E., Ed.; Museum Management Academy: Tokyo, Japan, 2004; pp. 3-19.

8. Assunção dos Santos, P. Introduction: To understand New Museology in the 21st Century. Cad. De Socio-Museol. 2010, 37, 5-11.

9. Heijnen, W. The new professional: Underdog or Expert? New Museology in the 21th century. Cad. De Socio-Museol. 2010, 37, 13-24.

10. International Council of Museums. Development of the Museum Definition according to ICOM Statutes (2007-1946). Available online: http://archives.icom.museum/hist_def_eng.html (accessed on 3 May 2020).

11. Smith, L. The Uses of Heritage; Routledge: London, UK, 2006.

12. Europeana. Available online: https://www.europeana.eu/en/about-us (accessed on 3 May 2020).

13. A Digital Agenda for Europe. Available online: https://eur-lex.europa.eu/legal-content/EN/TXT/?qid= 1588195013310\&uri=CELEX:52010DC0245 (accessed on 3 May 2020).

14. NMC Horizon Report: Museum Edition 2016. Available online: https:/library.educause.edu/ \{\}/media/files/ library/2016/1/2016hrmuseumEN.pdf (accessed on 3 May 2020).

15. Bosomtwe, O.; Buchner, A.; Janus, A.; Wierzbicka, M.; Wilkowski, M. Dobro Wspólne. Pasja i Praktyka. Cyfrowe Zasoby Kultury w Polsce; Centrum Cyfrowe Projekt Polska: Warsaw, Poland, 2018.

16. Pantalony, R.E. Managing Intellectual Property for Museums; WIPO: Geneva, Switzerland, 2013.

17. ICOM Definition of Museum. Available online: http://archives.icom.museum/definition.html (accessed on 3 May 2020).

18. ICOM Announces the Alternative Museum Definition That Will be Subject to a Vote. Available online: https://icom. museum/en/news/icom-announces-the-alternative-museum-definition-that-will-be-subject-to-a-vote/ (accessed on 3 May 2020).

19. Król, R. O genezie, roli i zadaniach współczesnych muzeów. In Prawo Muzeów; Włodarski, J., Zeidler, K., Eds.; Wolters Kluwer: Warsaw, Poland, 2008.

20. Golat, R. Nowe zasady działalności muzealnej w kontekście zadań samorządu terytorialnego (praktyczny komentarz do ustawy o muzeach). Muzealnictwo 2004, 45, 199-208.

21. Barańska, K. "Somewhere over the Rainbow”, czyli rola muzeów regionalnych w teraźniejszości. Wyzwania i zagrożenia oraz nieprzekraczalne granice w pełnionej misji. In Muzea Reginalne. Jaka przyszłość? Ogólnopolska konferencja muzeów reginalnych; Lolo, R., Sołtan, A., Sołtysiak, M., Tomaszewski, A., Eds.; Akademia Humanistyczna im. Aleksandra Gieysztora, Polski Komitet Narodowy ICOM, Stowarzyszenie Muzeów Polskich: Pułtusk, Poland, 2010.

22. Wilkoszewska, K. Muzeum- idea ambiwalentna. In Muzeum sztuki. Od Luwru do Bilbao; Popczyk, M., Ed.; Muzeum Śląskie: Katowice, Poland, 2006. 
23. Zalasińska, K. Muzea Publiczne. Studium Administracyjnoprawne; LexisNexis: Warsaw, Poland, 2013.

24. Vergo, P. Milczacy obiekt. In Muzeum sztuki. Antologia; Popczyk, M., Ed.; Universitas: Krakow, Poland, 2006.

25. Kowalski, W.; Gwoździewicz, P. Kolekcja. In Leksykon Prawa Ochrony Zabytków. 100 Podstawowych Pojęć; Zeidler, K., Ed.; Wydawnictwo CH Beck: Warsaw, Poland, 2010; p. 115.

26. Barańska, K. Muzeum w Sieci Znaczeń. Zarzadzanie z Perspektywy Nauk Humanistycznych; Wydawnictwo Attyka: Krakow, Poland, 2013.

27. Kostyrko, T. Dzieło sztuki w muzeum i jego aura. In Muzeum sztuki. Od Luwru do Bilbao; Popczyk, M., Ed.; Muzeum Śląskie: Katowice, Poland, 2006.

28. Kudelska, M. Kolekcja muzeów sztuki nowoczesnej i współczesnej a problem polityki pamięci. Zarządzanie w Kulturze 2018, 19, 185-209. [CrossRef]

29. National Institute for Museums and Public Collections. Statystyka muzeów. Muzea w 2018 roku; National Institute for Museums and Public Collections: Warsaw, Poland, 2019.

30. Jagodzińska, K. Czas Muzeów; Międzynarodowe Centrum Kultury: Krakow, Poland, 2014.

31. Głowacki, P. Przemiany w funkcjonowaniu państwowych galerii sztuki po 1989 roku. Pismo Naukowo-Artystyczne Akademii Sztuk Pięknych we Wrocławiu 2006, 4, 114-117.

32. Folga-Januszewska, D. Muzeum jako narzędzie edukacji. In Ekonomia Muzeum; Folga-Januszewska, D., Gutowski, B., Eds.; Universitas: Krakow, Poland, 2011.

33. Koźmiński, A.K.; Jemielniak, D. Zarządzanie od Podstaw; PWN: Warsaw, Poland, 2008.

34. Golat, R. Prawo Autorskie i Prawa Pokrewne; C.H. Beck: Warsaw, Poland, 2010.

35. Łada, P. Prawo Autorskie w Muzeum. Przewodnik ze Wzorami Umów; Wolters Kluwer: Warsaw, Poland, 2019.

36. Art. 24h. Available online: http://sztuka24h.edu.pl/ (accessed on 3 May 2020).

37. Creative Commons Licenses. Available online: https://creativecommons.org/use-remix/cc-licenses/ (accessed on 3 May 2020).

38. The Open Definition. Available online: https://opendefinition.org (accessed on 3 May 2020).

39. OpenGLAM. Available online: https://openglam.org (accessed on 3 May 2020).

40. Hofmokl, J.; Tarkowski, A.; Śliwowski, K. Otwartość w Publicznych Instytucjach Kultury; Creative Commons Polska: Gdansk-Warsaw, Poland, 2011.

41. COMMISSION OF THE EUROPEAN COMMUNITIES i2010-A European Information Society for Growth and Employment. Available online: https://eur-lex.europa.eu/LexUriServ/LexUriServ.do?uri=COM:2005: 0229:FIN:ENG:PDF (accessed on 3 May 2020).

42. National Institute for Museums and Public Collections. Prawne Aspekty Digitalizacji i Udostępniania Zbiorów Muzealnych przez Internet; National Institute for Museums and Public Collections: Warsaw, Poland, 2014.

43. Public Domain Mark. Available online: https://creativecommons.org/publicdomain/mark/1.0/deed.en (accessed on 3 May 2020).

44. Grodecka, K. Openness pyramid. Available online: https://commons.wikimedia.org/wiki/File:Piramida_ otwartosci.svg (accessed on 3 May 2020).

45. Simon, N. The Participatory Museum; Museum 2.0: Santa Cruz, CA, USA, 2010.

46. Czarnecki, S.; Janus, A.; Śliwowski, K.; Maźnica, Ł.; Laine-Zamoyska, M. Nowe Media, Ttechnologie i Otwartość w Instytucjach Kultury; Instytut Kultury Miejskiej: Gdansk, Poland, 2016.

47. National Institute for Museums and Public Collections. Raport. Strategia Rozwoju Muzealnictwa. Założenia Programowe; National Institute for Museums and Public Collections: Warsaw, Poland, 2012.

48. Ganicz, T. Domena Publiczna; KOED: Warsaw, Poland, 2012.

49. Śliwowski,K.; Grabowska, K. olityka Otwartości w Instytucji Kultury. Available online: https://medialabkatowice. eu/wp-content/uploads/2017/02/medialab_polityka.pdf (accessed on 3 May 2020).

50. Open Policy Statement MHP. Available online: http://muzhp.pl/pl/c/1526/deklaracja-polityki-otwartosci-mhp (accessed on 3 May 2020).

51. CC0 1.0 Universal. Public Domain Dedication. Available online: https://creativecommons.org/publicdomain/ zero/1.0/ (accessed on 3 May 2020).

52. Creative Commons Polska. Muzeum Historii Polski i Pierwsza Taka Polityka Otwartości. Available online: https://creativecommons.pl/2015/07/muzeum-historii-polski-i-pierwsza-taka-polityka-otwartosci/ (accessed on 3 May 2020).

53. Yin, R.K. Case Study Research: Design and Methods; Sage Publications: Thousand Oaks, CA, USA, 1984; ISBN 978-0-8039-2058-3. 
54. Stake, R.E. The Art of Case Study Research; SAGE Publications: Thousand Oaks, CA, USA, 1995; ISBN 978-0-8039-5767-1.

55. Stake, R.E. Qualitative Case Studies. In Qualitative Research, 3rd ed.; SAGE Publications: Thousand Oaks, CA, USA, 2005; pp. 443-467.

56. Siggelkow, N. Persuasion with case studies. Acad. Manag. J. 2007, 50, 20-24. [CrossRef]

57. Zachęta. Zachęta is a Place, Where the Most Interesting Phenomena of 20th and 21st Century Art. Available online: https://zacheta.art.pl/en/o-nas?setlang=1 (accessed on 3 May 2020).

58. Zachęta. Statut - Zachęta National Gallery of Art. Available online: http://bip.zacheta.art.pl/41/Statut/ (accessed on 3 May 2020).

59. Wróblewska, H. Interview on the Open Zachęta Program. Available online: http://koed.org.pl/?p=6877\& lang=pl (accessed on 3 May 2020).

60. Wróblewska, H. Talks About Openness in Cultural Institutions. Available online: https://ninateka.pl/film/ hanna-wroblewska-wstep-wolny-rozmowy-o-otwartosci-w-instytucjach-kultury (accessed on 3 May 2020).

61. Wróblewska, H. Otwarta Zachęta. In Otwartość w Publicznych Instytucjach Kultury; Hofmokl, J., Tarkowski, A., Śliwowski, K., Eds.; Creative Commons Polska: Gdansk-Warsaw, Poland, 2011.

62. Zachęta. Open Zachęta, or, How We Are Opening a Public Art Institution. Available online: https: //zacheta.art.pl/en/o-nas/otwarta-zacheta?setlang=1 (accessed on 3 May 2020).

63. Centrum Cyfrow Projekt: Polska. Centrum Cyfrowe Supports Openness and Engagement in the Digital World. Available online: https://centrumcyfrowe.pl/en/homepage/ (accessed on 3 May 2020).

64. Coalition for Open Education. Available online: http://koed.org.pl/?page_id=14323\&lang=en (accessed on 3 May 2020).

65. Creative Commons Poland. Available online: https://creativecommons.pl/ (accessed on 3 May 2020).

66. Koźmiński, A.K. Zarządzanie. In Zarzadzanie. Teoria i Praktyka; Koźmiński, A.K., Piotrowski, P., Eds.; PWN: Warsaw, Poland, 2006.

67. Gaweł, Ł. Kiedy dziedzictwo staje się dziedzictwem-kilka uwag w kontekście nauk o zarządzaniu. In Zarzadzanie Dziedzictwem. Problemy, Obszary, Definicje; Gaweł, Ł., Pokojska, W., Pudełko, A., Eds.; Wydawnictwo Attyka: Krakow, Poland, 2016.

(C) 2020 by the author. Licensee MDPI, Basel, Switzerland. This article is an open access article distributed under the terms and conditions of the Creative Commons Attribution (CC BY) license (http://creativecommons.org/licenses/by/4.0/). 